\title{
Determination of Iron Species in Samples of Iron-Fortified Food
}

\author{
Przemyslaw Niedzielski • Magdalena Zielinska-Dawidziak • Lidia Kozak • \\ Pawel Kowalewski • Barbara Szlachetka • Sylwia Zalicka • Weronika Wachowiak
}

Received: 28 January 2014 / Accepted: 10 March 2014 / Published online: 29 March 2014

(C) The Author(s) 2014. This article is published with open access at Springerlink.com

\begin{abstract}
The paper presents the determination of iron forms in food products. The procedure of sample extraction was developed and optimized, preserving the content of particular forms of iron. The colorimetric method using 2,2'-bipirydyl (measurements at $520 \mathrm{~nm}$ ) was applied in Fe(II) determinations, while in $\mathrm{Fe}(\mathrm{III})$ determinations, the colorimetric method with potassium thiocyanate (measurements at $470 \mathrm{~nm}$ ) was applied. The total content of iron was determined by the technique of atomic absorption spectrometry, which allowed for the determination of iron content in organic and inorganic complex compounds. Detection limits of $1 \mathrm{mg} \mathrm{kg}^{-1}$ were obtained for all determined iron forms, with the precision ranging between $0.7 \%$ and $1.5 \%$ for $10 \mathrm{mg} \mathrm{kg}^{-1}$ concentration. The optimized analytical procedure was applied in the determinations of iron forms in iron-fortified food products.
\end{abstract}

Keywords Iron · Speciation · Food analysis · Bioactive food · Spectrophotometry $\cdot$ Atomic absorption spectrometry

P. Niedzielski $(\bowtie) \cdot$ L. Kozak $\cdot$ P. Kowalewski $\cdot$ B. Szlachetka S. Zalicka $\cdot$ W. Wachowiak

Department of Analytical Chemistry, Faculty of Chemistry, Adam Mickiewicz University, 89b Umultowska Street, 61-614 Poznan, Poland

e-mail: pnied@amu.edu.pl

M. Zielinska-Dawidziak

Department of Food Biochemistry and Analysis, Poznan University of Life Sciences, 48 Mazowiecka Street, 60-623 Poznan, Poland

W. Wachowiak

Faculty of Geographical and Geological Sciences, Pila Didactic Centre, Adam Mickiewicz University, 15 Kolobrzeska Street, 64-720 Pila, Poland

\section{Introduction}

Enrichment of food with iron is one of the methods of supplying this element to our body. The form of supplementation is vital due to its potential assimilative properties. An easily assimilable form of iron is ferritin, a metalloprotein capable of accumulating iron. The accumulation occurs at high concentrations of iron salts in the growth environment of plants, and using ferritin over-expression has become a method of supplementing food products with iron (Goto et al. 1999; Lucca et al. 2001).

There are two types of nutritional iron usually distinguished: heme (stable porphyrin complexes) and non-heme (from weak complexes or 'free' iron). These forms differ markedly in the molecular mechanisms of their absorption and bioavailability. Thus, from a nutritional point of view, both the total amount of iron and the form of iron in food are significant (Schönfeldt and Hall 2011). Several new ideas have been reported in the literature in recent years. Suggestions for other molecular mechanisms of ferritin absorption have also appeared (Theil et al. 2012; Kalgaonkar and Lönnerdal 2009). Discussion on their receptor-mediated endocytosis in the intestines (Theil et al. 2012), independence from the heme and ferrous salt absorption (Lucca et al. 2001), as well as the questions about degradation during the food production processes prompt us to undertake studies on the ability of phytoferritin to survive in different cereal products, subjected to various types of treatment technology. The protein has unusual properties: it is resistant to many hydrolytic enzymes and temperature (up to $85^{\circ} \mathrm{C}$ ) (Lönnerdal 2003; Liu and Theil 2005; Hoppler et al. 2008). However, extreme food processing may induce protein denaturation or hydrolytic degradation (Hoppler et al. 2008), which results in ferritin iron release and transition to ionic forms $\left(\mathrm{Fe}^{2+}, \mathrm{Fe}^{3+}\right)$ (Lönnerdal 2003), and absorption by the gut receptor DMT1 (Andrews and Schmidt 2007; McKie et al. 2001). Therefore, it 
seems necessary to develop an analytical method of iron speciation in food fortified with ferritin.

For higher concentrations (more than $1 \mathrm{mg} \mathrm{kg}^{-1}$ ) of iron forms, the colorimetric methods have been used in speciation analyses. In colorimetric determinations of iron, the most commonly used methods were those using coloured complexes formed by iron (Hosseinimehr et al. 2001) with thiocyanate ions, 2,2'-bipirydyl and 1,10-phenanthroline. The following components react with $\mathrm{Fe}(\mathrm{II}): 2,2$ '-bipirydyl forming a red complex with the maximum absorption at $520 \mathrm{~nm}$ (Whitehead and Malik 1975) and 1,10-phenanthroline, also forming a red complex with the maximum absorption of approx. $510 \mathrm{~nm}$ (Harvey et al. 1955; Lozano-Camargo et al. 2007). In turn, thiocyanate ions and $\mathrm{Fe}$ (III) form a red complex with the maximum absorption at $475-485 \mathrm{~nm}$ (Tarafder and Thakur 2005), while 1,10-phenanthroline forms a yellow complex with the maximum absorption of $396 \mathrm{~nm}$ (Harvey et al. 1955).

Although iron complexes with other reagents (Filik and Giray 2012) are also used in colorimetric determinations of iron content, the three methods presented above have been most frequently applied in iron analysis. Due to the selective formation of complexes with different iron forms, colorimetric methods have been widely used in speciation analyses of this element. For instance, the method based on iron reaction with 1,10phenanthroline has been used in selective determinations of $\mathrm{Fe}$ (II) and Fe(III) contents. The above method uses both the fact of forming multi-coloured complexes determined sequentially at different wavelengths: 396 and $512 \mathrm{~nm}$ for $\mathrm{Fe}(\mathrm{III})$ and $\mathrm{Fe}(\mathrm{II})$, respectively (Harvey et al. 1955), and sequential determinations of $\mathrm{Fe}$ (II) and total iron following the reduction of $\mathrm{Fe}$ (III) to $\mathrm{Fe}$ (II) (Feres and Reis 2005; Galhardo and Masini 2001). 1,10Phenanthroline has also been used in sequential determination of iron forms in direct colorimetric determinations combined with colorimetric titration (Kochana and Parczewski 1997). A previous paper (Kozak et al. 2013) presented the procedure of simultaneous determination of Fe(II), Fe(III) and complexed iron in sediment samples by a new tandem analytical system using the phenomena of particle absorption and atomic absorption, working in the flow-injection mode and equipped with two detectors: a diode array spectrophotometer and an atomic absorption spectrometer. The procedure applied in the determinations of iron forms in geochemical studies of sediments and soils could not be used in the studies of food due to the colour of extracts and potential presence of sample components in the form of colloid solutions, hence the necessity to develop a new methodology which would enable the analyses of food products.

In this paper, the determination of $\mathrm{Fe}(\mathrm{II}), \mathrm{Fe}(\mathrm{III})$ and complexed iron (including ferritin) in food samples will be presented. The conditions for iron forms extraction from food samples will be shown, as well as the influence of extraction conditions on iron speciation. The developed analytical procedure will be applied in iron speciation analysis in food products.

\section{Experimental}

Instruments

A Slandi LF300 (Slandi, Poland) photometer was used in colorimetric analyses, which allowed for the absorbance measurements at 470 and $520 \mathrm{~nm}$. In the determinations of total iron content, a SpectrAA 220FS (Varian, Australia) atomic absorption spectrometer with air-acetylene flame atomization was applied, equipped with an HCL lamp used in iron determinations (wavelength $248.3 \mathrm{~nm}$, slit $0.2 \mathrm{~nm}$, lamp current $10 \mathrm{~mA}$ ).

\section{Reagents}

Only analytically pure reagents and water with $18 \mathrm{M} \Omega \mathrm{cm}$ resistivity obtained in a Direct-Q 3UV (Millipore, Germany) device were used in the determinations. Standard solutions of iron species $\mathrm{Fe}(\mathrm{II})$ and $\mathrm{Fe}(\mathrm{III})$ of concentration $1.00 \mathrm{mg} \mathrm{ml}^{-1}$ were prepared from weights of the following salts: ferrous ammonium sulphate hexahydrate and ferric ammonium sulphate dodecahydrate (both chemicals obtained from Acros). An analytical standard of total iron was also used in the atomic absorption spectrometry $\left(\mathrm{Fe}\left(\mathrm{NO}_{3}\right)_{3}\right)$ at concentration $1.000 \mathrm{mg} \mathrm{ml}^{-1}$ (Merck, Germany). Standard solutions of lower concentrations were prepared on the day of the analyses. The following reagents were used in the study (obtained from the Polish Chemical Reagents POCh): acetate buffer ( $90 \mathrm{~g}$ sodium acetate $\left[\mathrm{CH}_{3} \mathrm{COONa} \cdot 3 \mathrm{H}_{2} \mathrm{O}\right]$ was dissolved in water, $48 \mathrm{ml}$ concentrated acetic acid was added, then the solution was filled up to $200 \mathrm{ml}$ with water and stirred); 2,2'-bipirydyl $\left[\mathrm{C}_{10} \mathrm{H}_{8} \mathrm{~N}_{2}\right]$, $0.5 \%(\mathrm{~m} / \mathrm{m})$ solution; potassium thiocyanate $[\mathrm{KSCN}], 5 \%$ $(\mathrm{m} / \mathrm{m})$ solution, hydrochloric acid $[\mathrm{HCl}] 0.1,0.5,1.0$ and $2.0 \mathrm{~mol} \mathrm{l}^{-1}$ solutions; nitric acid $\left[\mathrm{HNO}_{3}\right]$ approx. $65 \%$; hydrogen peroxide $\left[\mathrm{H}_{2} \mathrm{O}_{2}\right]$ approx. $30 \%$. The iron concentration in reagent blank sample has been found below detection limit.

\section{Samples}

A total of 25 different samples of food fortified with iron by the addition of soy bean seeds (radicle with cotyledons) sprouted for 7 days in $\mathrm{FeSO}_{4}$ were prepared for the analyses. The obtained material was dried, ground or cut into $2-5 \mathrm{~mm}$ fractions and added to different cereal products. The products with the composition unknown to us were delivered by the producer, with the annotation that they are produced on the basis of rice, wheat or corn grains.

\section{Samples Preparation}

Food samples were dried in the temperature of $50{ }^{\circ} \mathrm{C}$, ground to $<0.1 \mathrm{~mm}$ grain diameter and sieved. Each sample $(2.00 \mathrm{~g})$ was subjected to extraction with $20.0 \mathrm{ml}$ hydrochloric acid in the following conditions: 
a0.1 - acid concentration $0.1 \mathrm{~mol} \mathrm{l}^{-1}$, sample extracted at $25^{\circ} \mathrm{C}$ in $60 \mathrm{~min}$ under cover

a0.5 - acid concentration $0.5 \mathrm{~mol} \mathrm{l}^{-1}$, sample extracted at $25^{\circ} \mathrm{C}$ in 60 min under cover

a1.0 - acid concentration $1.0 \mathrm{~mol} \mathrm{l}^{-1}$, sample extracted at $25^{\circ} \mathrm{C}$ in 60 min under cover

a2.0 - acid concentration $2.0 \mathrm{~mol}^{-1}$, sample extracted at $25^{\circ} \mathrm{C}$ in 60 min under cover

w0.1 - acid concentration $0.1 \mathrm{~mol} \mathrm{l}^{-1}$, sample heated at $80^{\circ} \mathrm{C}$ in 60 min under reflux condenser

w0.5 - acid concentration $0.5 \mathrm{~mol} \mathrm{l}^{-1}$, sample heated at $80^{\circ} \mathrm{C}$ in 60 min under reflux condenser

w1.0 - acid concentration $1.0 \mathrm{~mol} \mathrm{l}^{-1}$, sample heated at $80{ }^{\circ} \mathrm{C}$ in 60 min under reflux condenser

w2.0 - acid concentration $2.0 \mathrm{~mol} \mathrm{l}^{-1}$, sample heated at $80{ }^{\circ} \mathrm{C}$ in 60 min under reflux condenser

The description of the sample that has been used consequently follows Scheme 1.

After filtration through a medium-size qualitative filter (earlier rinsed with $200 \mathrm{ml}$ distilled water) and filled up to $20.0 \mathrm{ml}$, the obtained solutions were subjected to analysis. Directly prior to the analysis, the solutions were diluted ten times with water. The course of sample preparation was repeated twice $(n=2)$ for each sample of iron-fortified food.

\section{Methodology}

The methodology of determination of iron content is presented in Fig. 1. It involved three basic stages.

\section{Determination of Total Iron}

The total content of iron was determined using atomic absorption spectrometry with air-acetylene flame atomization.

\section{Determination of Ionic Forms of Iron}

$\mathrm{Fe}(\mathrm{II})$ content was determined in reaction with 2,2'-bipirydyl in the environment of acetate buffer ( $\mathrm{pH} 4.5)$ using photometry (wavelength $520 \mathrm{~nm}$ ), while Fe(III) content was determined in reaction with thiocyanate in the environment of hydrochloric acid $(\mathrm{pH}<2.0)$ using photometry (wavelength $470 \mathrm{~nm}$ ). For the determination of Fe(II) content the $0.5 \mathrm{ml}$ of acetic buffer and $0.5 \mathrm{ml}$ of 2,2'-bipirydyl solution has been

$\mathrm{w}($ warm $)$ - extraction temperature $80^{\circ} \mathrm{C}$

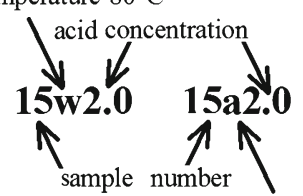

a(ambient)-extraction temperature $25^{\circ} \mathrm{C}$

Scheme 1 The rules of the sample description

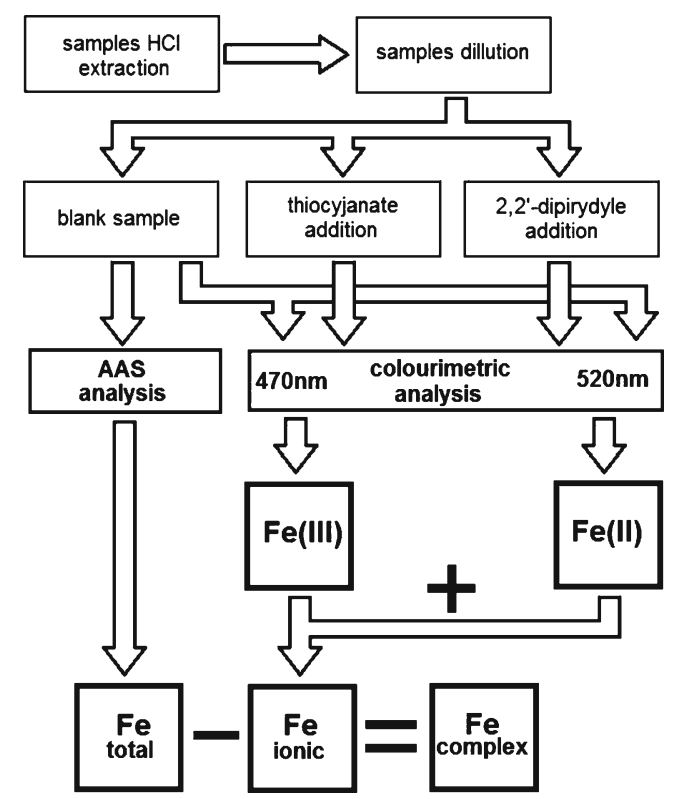

Fig. 1 Schematic diagram of iron species determination procedure

added to $5.0 \mathrm{ml}$ of sample. The sample has been ready to spectrophotometric analysis after $10 \mathrm{~min}$. For the determination of $\mathrm{Fe}$ (III) content, $0.5 \mathrm{ml}$ of hydrochloric acid $2 \mathrm{~mol}^{-1}$ solution and $0.5 \mathrm{ml}$ of potassium thiocyanate solution were added to $5.0 \mathrm{ml}$ of the sample. The sample was ready for spectrophotometric analysis after $10 \mathrm{~min}$. Before the absorbance was measured for each sample, it was measured for the same sample (sample after the extraction was diluted ten times by water) without any reagents added (photometric blank) and the obtained value was used to correct the result of iron forms content.

This was intended to reduce interference related to the colour of sample and possible presence of sample components in the colloid form. The ionic iron was the sum of Fe(II) and $\mathrm{Fe}(\mathrm{III})$ contents.

\section{Calculating the Content of Bound Iron}

The content of iron in the bound form (organic and inorganic complexed iron compounds) was calculated from the difference between the total iron content obtained during the atomic absorption spectrometry and ionic iron, which was the sum of $\mathrm{Fe}(\mathrm{II})$ and $\mathrm{Fe}(\mathrm{III})$ contents obtained in the photometric analyses.

\section{Validation}

The above analytical methodology was validated. The following values were obtained: slope of calibration curve 0.1484 $\left(\mathrm{mg} \mathrm{l}^{-1}\right)^{-1}$, correlation coefficient $\left(R^{2}=0.9912\right)$, detection limit $1 \mathrm{mg} \mathrm{kg}^{-1}$, precision $1.4 \%$ for $10 \mathrm{mg} \mathrm{kg}^{-1}$ in $\mathrm{Fe}$ (II) determinations, slope of calibration curve $0.1308\left(\mathrm{mg} \mathrm{l}^{-1}\right)^{-1}$, correlation coefficient $\left(R^{2}=0.9989\right)$, detection limit 
Table 1 The results of determination of iron forms in samples extracted by $2 \mathrm{~mol}^{-1}$ hydrochloric acid in ambient temperature (a) and $80{ }^{\circ} \mathrm{C}(\mathrm{w})$

\begin{tabular}{|c|c|c|c|c|c|c|c|c|c|c|}
\hline Sample & Description & $\begin{array}{l}\mathrm{Fe}(\mathrm{II}) \\
\left(\mathrm{mg} \mathrm{kg}^{-1}\right)\end{array}$ & $\begin{array}{l}\mathrm{Fe}(\mathrm{III}) \\
\left(\mathrm{mg} \mathrm{kg}^{-1}\right)\end{array}$ & $\begin{array}{l}\text { Fe complex } \\
\left(\mathrm{mg} \mathrm{kg}^{-1}\right)\end{array}$ & $\begin{array}{l}\text { Fe tot } \\
\left(\mathrm{mg} \mathrm{kg}^{-1}\right)\end{array}$ & $\begin{array}{l}\text { Fe miner } \\
\left(\mathrm{mg} \mathrm{kg}^{-1}\right)\end{array}$ & $\begin{array}{l}\text { Recovery } \\
(\%)\end{array}$ & $\begin{array}{l}\mathrm{Fe}(\mathrm{II}) \\
(\%)\end{array}$ & $\begin{array}{l}\text { Fe compl } \\
(\%)\end{array}$ & \\
\hline \multirow[t]{6}{*}{ A. Rice products } & $1 \mathrm{a} 2.0$ & 6.4 & $<1$ & 10 & 17 & 18 & 91.7 & 38.7 & 61.3 & \\
\hline & $1 \mathrm{w} 2.0$ & 6.8 & $<1$ & 11 & 18 & 18 & 98.3 & 38.4 & 61.6 & \\
\hline & $2 \mathrm{a} 2.0$ & 15 & $<1$ & 24 & 39 & 59 & 66.1 & 39.2 & 60.8 & \\
\hline & $2 \mathrm{w} 2.0$ & 25 & $<1$ & 30 & 55 & 59 & 92.4 & 45.5 & 54.5 & \\
\hline & $3 \mathrm{a} 2.0$ & 41 & $<1$ & 54 & 95 & 120 & 78.8 & 43.4 & 56.6 & \\
\hline & $3 \mathrm{w} 2.0$ & 89 & $<1$ & 25 & 114 & 120 & 95.0 & 77.9 & 22.1 & Need \\
\hline \multirow[t]{4}{*}{ B. Corn products } & $4 \mathrm{a} 2.0$ & 5.9 & $<1$ & 2.7 & 8.6 & 38 & 22.6 & 68.6 & 31.4 & \\
\hline & $4 w 2.0$ & 31 & $<1$ & $\begin{array}{l}3.2 \\
\quad \text { correction }\end{array}$ & 34 & 38 & 89.2 & 90.6 & 9.4 & Need \\
\hline & $5 \mathrm{a} 2.0$ & 70 & $<1$ & 73 & 144 & 250 & 57.5 & 49.0 & 51.0 & \\
\hline & $5 w 2.0$ & 234 & $<1$ & $\begin{array}{l}31 \\
\quad \text { correction }\end{array}$ & 265 & 250 & 106.0 & 88.3 & 11.7 & Need \\
\hline $6 \mathrm{a} 2.0$ & 31 & $<1$ & 66 & 97 & 125 & 77.6 & 32.2 & 67.8 & & \\
\hline $\begin{array}{l}6 \mathrm{w} 2.0 \\
\text { correction }\end{array}$ & 115 & $<1$ & 13 & 128 & 125 & 102.4 & 89.8 & 10.2 & Need & \\
\hline \multirow{9}{*}{$\begin{array}{l}\text { C. Corn/wheat } \\
\text { products }\end{array}$} & $7 \mathrm{a} 2.0$ & 9.1 & $<1$ & 20 & 29 & 61 & 46.9 & 31.8 & 68.2 & \\
\hline & $7 \mathrm{w} 2.0$ & 32 & $<1$ & $\begin{array}{l}25 \\
\text { correction }\end{array}$ & 57 & 61 & 93.8 & 55.9 & 44.1 & Need \\
\hline & $8 \mathrm{a} 2.0$ & 5.7 & $<1$ & 10 & 15 & 28 & 54.6 & 37.3 & 62.7 & \\
\hline & $8 \mathrm{w} 2.0$ & 18 & $<1$ & ${ }^{8}$ correction & 27 & 28 & 94.6 & 69.1 & 30.9 & Need \\
\hline & $9 \mathrm{a} 2.0$ & 33 & $<1$ & 18 & 51 & 54 & 94.1 & 64.2 & 35.8 & \\
\hline & $9 \mathrm{w} 2.0$ & 36 & $<1$ & 21 & 57 & 54 & 105.2 & 63.0 & 37.0 & \\
\hline & $10 \mathrm{a} 2.0$ & 16 & $<1$ & 20 & 36 & 52 & 69.6 & 45.0 & 55.0 & \\
\hline & $10 \mathrm{w} 2.0$ & 36 & $<1$ & $\begin{array}{l}15 \\
\text { correction }\end{array}$ & 51 & 52 & 97.5 & 70.2 & 29.8 & Need \\
\hline & $11 \mathrm{a} 2.0$ & 1.1 & $<1$ & 11 & 12 & 18 & 67.2 & 9.1 & 90.9 & \\
\hline $\begin{array}{l}11 \mathrm{w} 2.0 \\
\text { correction }\end{array}$ & 7.9 & $<1$ & 8.9 & 17 & 18 & 93.3 & 47.0 & 53.0 & Need & \\
\hline $12 \mathrm{a} 2.0$ & 8.7 & $<1$ & 8.6 & 17 & 16 & 107.8 & 50.4 & 49.6 & & \\
\hline $\begin{array}{l}12 \mathrm{w} 2.0 \\
\text { correction }\end{array}$ & 5.5 & $<1$ & 8.7 & 14 & 16 & 88.8 & 38.7 & 61.3 & Need & \\
\hline \multirow[t]{5}{*}{ D. Wheat products } & $13 \mathrm{a} 2.0$ & 0 & $<1$ & 63 & 63 & 155 & 40.8 & 0.0 & 100.0 & \\
\hline & $13 \mathrm{w} 2.0$ & 49 & $<1$ & $\begin{array}{l}101 \\
\quad \text { correction }\end{array}$ & 150 & 155 & 96.8 & 32.9 & 67.1 & Need \\
\hline & $14 \mathrm{a} 2.0$ & 22 & $<1$ & 36 & 59 & 145 & 40.4 & 37.9 & 62.1 & \\
\hline & $14 \mathrm{w} 2.0$ & 53 & $<1$ & 96 & 149 & 145 & 102.8 & 35.8 & 64.2 & \\
\hline & $15 \mathrm{a} 2.0$ & 22 & $<1$ & 36 & 58 & 155 & 37.5 & 38.5 & 61.5 & \\
\hline $15 \mathrm{w} 2.0$ & 53 & $<1$ & 103 & 155 & 155 & 100.3 & 34.0 & 66.0 & & \\
\hline \multirow[t]{4}{*}{ E. Mixed products } & $16 \mathrm{a} 2.0$ & 20 & $<1$ & 28 & 48 & 200 & 24.0 & 41.3 & 58.8 & \\
\hline & $16 \mathrm{w} 2.0$ & 86 & $<1$ & 102 & 188 & 200 & 94.2 & 45.6 & 54.4 & \\
\hline & $17 \mathrm{a} 2.0$ & 22 & $<1$ & 36 & 59 & 74 & 79.2 & 37.9 & 62.1 & \\
\hline & $17 \mathrm{w} 2.0$ & 61 & $<1$ & 17 & 78 & 74 & 105.1 & 77.9 & 22.1 & Need \\
\hline \multirow[t]{4}{*}{ F. Desserts } & $18 \mathrm{a} 2.0$ & 45 & $<1$ & 50 & 95 & 151 & 63.0 & 47.4 & 52.6 & \\
\hline & $18 \mathrm{w} 2.0$ & 59 & $<1$ & 86 & 145 & 151 & 96.0 & 40.8 & 59.2 & \\
\hline & $19 \mathrm{a} 2.0$ & 44 & $<1$ & 72 & 116 & 129 & 89.9 & 37.8 & 62.2 & \\
\hline & $19 \mathrm{w} 2.0$ & 71 & $<1$ & 64 & 135 & 129 & 104.6 & 52.3 & 47.7 & Need \\
\hline
\end{tabular}


Table 1 (continued)

\begin{tabular}{|c|c|c|c|c|c|c|c|c|c|c|}
\hline Sample & Description & $\begin{array}{l}\mathrm{Fe}(\mathrm{II}) \\
\left(\mathrm{mg} \mathrm{kg}^{-1}\right)\end{array}$ & $\begin{array}{l}\mathrm{Fe}(\mathrm{III}) \\
\left(\mathrm{mg} \mathrm{kg}^{-1}\right)\end{array}$ & $\begin{array}{l}\text { Fe complex } \\
\left(\mathrm{mg} \mathrm{kg}^{-1}\right)\end{array}$ & $\begin{array}{l}\text { Fe tot } \\
\left(\mathrm{mg} \mathrm{kg}^{-1}\right)\end{array}$ & $\begin{array}{l}\text { Fe miner } \\
\left(\mathrm{mg} \mathrm{kg}^{-1}\right)\end{array}$ & $\begin{array}{l}\text { Recovery } \\
(\%)\end{array}$ & $\begin{array}{l}\mathrm{Fe}(\mathrm{II}) \\
(\%)\end{array}$ & $\begin{array}{l}\text { Fe compl } \\
(\%)\end{array}$ & \\
\hline & $20 \mathrm{a} 2.0$ & 30 & $<1$ & 80 & 110 & 136 & 80.9 & 27.6 & 72.4 & \\
\hline & $20 \mathrm{w} 2.0$ & 67 & $<1$ & $\begin{array}{l}73 \\
\quad \text { correction }\end{array}$ & 140 & 136 & 102.9 & 48.1 & 51.9 & Need \\
\hline $21 \mathrm{a} 2.0$ & 40 & $<1$ & 66 & 101 & 141 & 71.6 & 39.9 & 65.0 & & \\
\hline $21 w 2.0$ & 55 & $<1$ & 81 & 136 & 141 & 96.2 & 40.6 & 59.4 & & \\
\hline \multirow{6}{*}{$\begin{array}{l}\text { G. Ready-to-cook } \\
\text { products }\end{array}$} & $22 \mathrm{a} 2.0$ & 4.5 & $<1$ & 19 & 24 & 56 & 42.7 & 18.8 & 81.2 & \\
\hline & $22 \mathrm{w} 2.0$ & 28 & $<1$ & 24 & 52 & 56 & 92.9 & 53.1 & 46.9 & \\
\hline & $23 \mathrm{a} 2.0$ & 453 & 126 & 1,059 & 1,638 & 2,650 & 61.8 & 27.6 & 64.7 & \\
\hline & $23 w 2.0$ & 1,156 & 174 & $\begin{array}{l}1,324 \\
\quad \text { correction }\end{array}$ & 2,654 & 2650 & 100.2 & 43.6 & 49.9 & Need \\
\hline & $24 \mathrm{a} 2.0$ & 3.7 & $<1$ & 14 & 18 & 25 & 70.0 & 21.1 & 78.9 & \\
\hline & $24 \mathrm{w} 2.0$ & 16 & $<1$ & $\begin{array}{l}6.9 \\
\text { correction }\end{array}$ & 23 & 25 & 93.2 & 70.4 & 29.6 & Need \\
\hline $25 \mathrm{a} 2.0$ & 22 & $<1$ & 42 & 64 & 155 & 41.0 & 34.4 & 65.6 & & \\
\hline $25 \mathrm{w} 2.0$ & 63 & $<1$ & 93 & 156 & 155 & 100.6 & 40.1 & 59.9 & & \\
\hline
\end{tabular}

Fe tot total iron concentration in hydrochloric acid extract, Fe miner total iron concentration after sample mineralization following the USEPA Method 3050B, recovery the recovery in hydrochloric acid extraction compared with USEPA 3050B mineralization, need correction the extraction in higher temperature changed the iron speciation
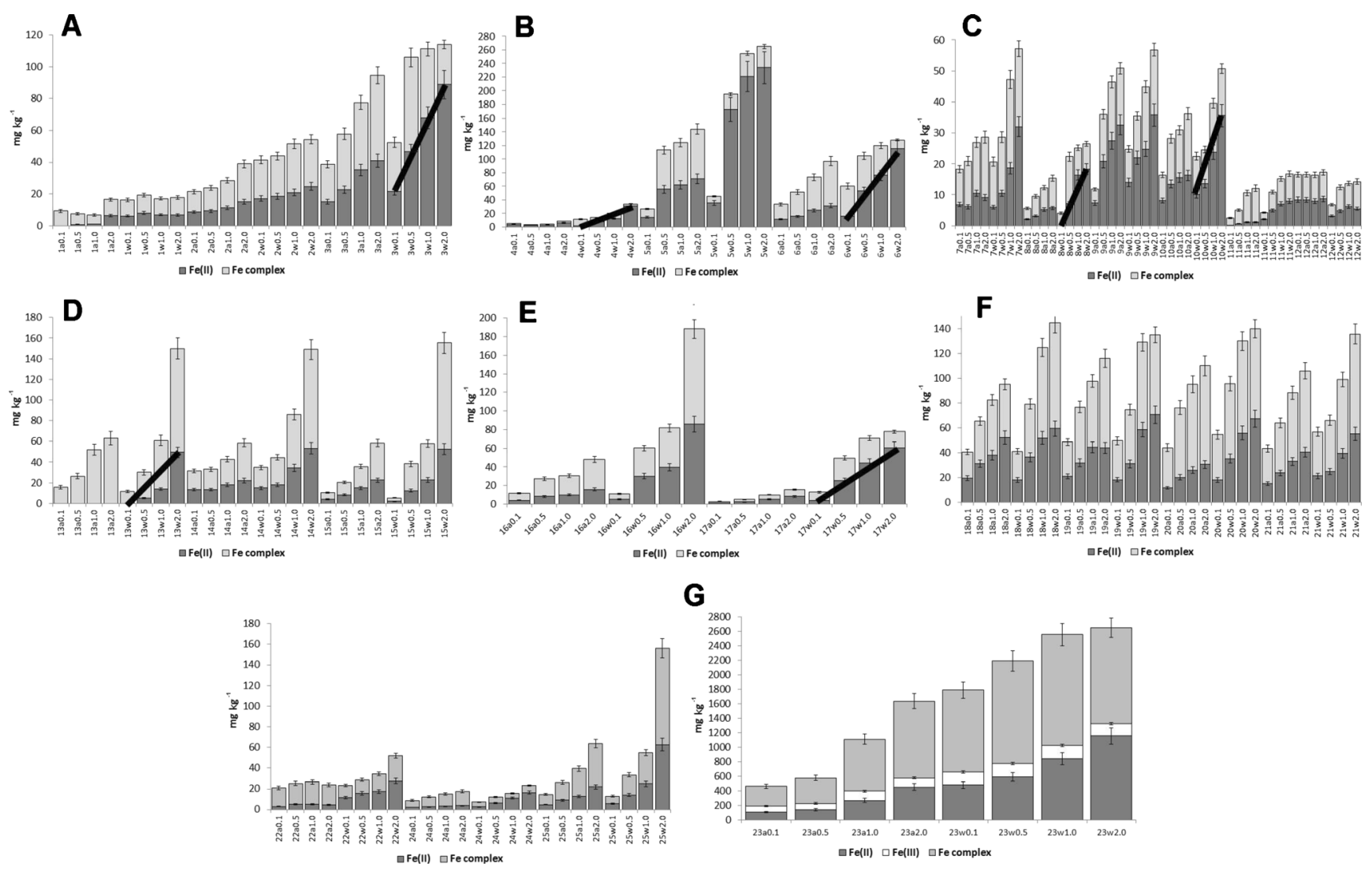

Fig. 2 Presence of Fe(II) and Fe complexed (and Fe(III) for the last graph) in food extracts obtained for different extraction procedures. Samples description: $a$ extraction in ambient temperature $\left(20^{\circ} \mathrm{C}\right), w$

extraction on a hot plate $\left(80{ }^{\circ} \mathrm{C}\right) ; 0.1,0.5,1.0,2.0$ hydrochloric acid concentration mol $\mathrm{l}^{-1}$; A-G group of food products (description follows Table 1); the lines show statistically significant trends 

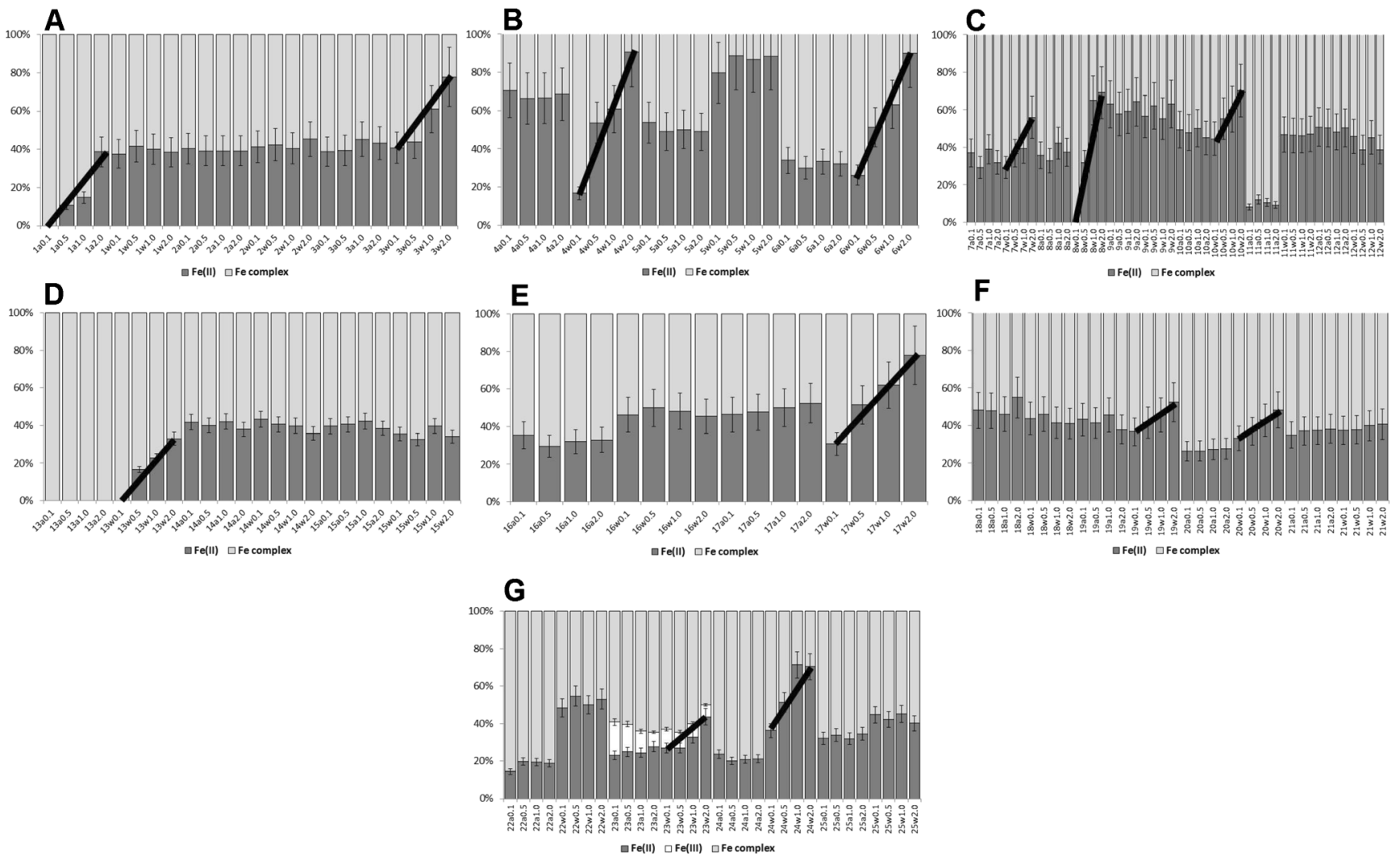

Fig. 3 Percentage of Fe(II) and Fe complexed (and Fe(III) for last graph) in food extracts obtained for different extraction procedures. Samples description: $a$ extraction in ambient temperature $\left(20^{\circ} \mathrm{C}\right), w$ extraction on

$1 \mathrm{mg} \mathrm{kg}^{-1}$, precision $1.5 \%$ for $10 \mathrm{mg} \mathrm{kg}^{-1}$ in Fe(III) determinations, and detection limit $1 \mathrm{mg} \mathrm{kg}^{-1}$, precision $0.7 \%$ for $10 \mathrm{mg} \mathrm{kg}^{-1}$ in the determinations of total iron content. Moreover, the precision of determinations was defined as the relative standard deviation (RSD) obtained for repetition (the same day, the same analyst) of the sample analysis $(n=6)$ for the whole analytical procedure (including sample preparation). The analytical (linear) range of procedure has been found as $100 \mathrm{mg} \mathrm{kg}^{-1}$ without sample dilution and $1,000 \mathrm{mg} \mathrm{kg}^{-1}$ after ten times dilution of sample follow described procedure.

The obtained parameter values characteristic for the analytical method indicate a realistic possibility of its application in the determinations of content of iron forms in food sample extracts. The precision obtained for the whole analytical procedure comprising the treble repetition of the extraction cycle and the measurement of content of iron forms with values below $20 \%$, confirm the possibility to apply the described method in scientific studies.

Due to the lack of reference materials for iron speciation studies in food products, the recovery of the standard (for $\mathrm{Fe}(\mathrm{II}), \mathrm{Fe}(\mathrm{III})$ and total $\mathrm{Fe}$, respectively) added to the sample extract was also determined. High recovery of the addition to the sample was found: $89.5 \pm 4.3 \%, 107.2 \pm 6.9 \%$ and $102.1 \pm$ $3.4 \%$ for $\mathrm{Fe}(\mathrm{II}), \mathrm{Fe}(\mathrm{III})$ and total $\mathrm{Fe}$, respectively, which a hot plate $\left(80^{\circ} \mathrm{C}\right) ; 0.1,0.5,1.0,2.0$ hydrochloric acid concentration mol $1^{-1}$; A-G group of food products (description follows Table 1); the lines show the statistically significant trends

confirmed the possibilities of practical application of the described analytical procedures in food analysis. The standard addition method has been additionally used to define the accuracy of iron forms determination - the selectivity of described procedures was high.

\section{Results and Discussion}

Optimisation of the Analytical Procedure

In accordance with the above methodology, 25 different food samples (Table 1 ) were analyzed and $2 \times 200$ solutions (double samples) were obtained, in which the content of ionic iron forms $\mathrm{Fe}(\mathrm{II}), \mathrm{Fe}$ (III) and complexed iron compounds was determined. The results of the analyses are presented in Fig. 2.

The presence of trivalent iron was found only in one sample of a ready-to-cook product. In the other samples, iron occurred in the form $\mathrm{Fe}$ (II) and in the form of complexed compounds. Along with the increase in hydrochloric acid concentration, the increase in the determined total iron concentration was observed. Higher iron contents were determined during the extraction in the temperature of $80^{\circ} \mathrm{C}$ than during the extraction conducted in room temperature. The higher concentration used in hydrochloric acid extraction 
and higher extraction temperature cause the increase in the efficiency of iron extraction from food product samples. The concentration of iron extracted with $2.0 \mathrm{~mol} \mathrm{l}^{-1}$ hydrochloric acid in the temperature of $80{ }^{\circ} \mathrm{C}$ constituted $85-105 \%$ of the total iron content following sample mineralization with a mixture of nitric and hydrochloric acids with the addition of hydrogen peroxide in accordance with the USEPA Method 3050B procedure (Table 1). It may, therefore, be assumed that this is the only extraction procedure that leads to obtaining representative results of total iron content in a sample. During the extraction with hydrochloric acid, different iron forms may be extracted with varied efficiency. Moreover, the extraction may cause the transformation of iron forms in a sample. In Fig. 2, using a line, the samples have been shown for which changes in concentrations of iron forms differ from the changes in their total content. This may suggest that the above presented different extractions of forms or their transformations indeed occur during the extraction of some samples. This is confirmed in Fig. 3, which presents the percentage participation of particular iron forms.

For most samples, the percentage content of iron forms in the extract is constant, certain differences may be observed between the extraction in room temperature and the extraction at $80^{\circ} \mathrm{C}$. This suggests that, regardless of the total iron content in extracts, the element is found in the forms whose participation in the total iron content is similar. The extraction, therefore, does not disturb the iron speciation in samples. However, in the case of the extraction of several samples (with the exception of one case, this only refers to the extraction at $80^{\circ} \mathrm{C}$ ), along with the increase in hydrochloric acid concentration, a change in the percentage participation of particular iron forms was observed. The iron content in the complexed form decreased, while the content of Fe(II) increased. This is presented in Fig. 3, using the change trend lines. In this case, the extraction disturbs the balanced presence of iron forms. Such a situation was observed for each group of the studied food products, and it may be assumed that the susceptibility to the disturbances of the speciation system is an individual feature of a given sample. On the one hand, due to the highest effectiveness, the best procedure of sample preparation seems to be the extraction using $2.0 \mathrm{~mol}^{-1}$ hydrochloric acid at $80{ }^{\circ} \mathrm{C}$. On the other hand, however, for certain individual samples (difficult to identify) such extraction may disturb iron speciation. Table 1 presents the similarities and differences (statistically significant, marked as 'need correction') of iron forms participation in the total content of the element (due to the presence of $\mathrm{Fe}$ (III) in only one sample, the content of this form has been omitted) in the extraction with hydrochloric acid in room temperature (a) and at $80^{\circ} \mathrm{C}(\mathrm{w})$. As results from the data presented in Fig. 3 and in Table 1, the total iron content in food samples should be determined following a sample extraction with $2.0 \mathrm{~mol}^{-1}$ hydrochloric acid at $80{ }^{\circ} \mathrm{C}$. However, during such extraction the disturbance in the content of iron forms may occur for some samples (the increase in $\mathrm{Fe}$ (II) percentage content at the decreased percentage of $\mathrm{Fe}$ content in complexed compounds). However, no change in the percentage of Fe(III) content occurs, although this observation only refers to the analysis of a single sample. The speciation of iron in all samples is probably preserved in the case of their extraction with $2.0 \mathrm{~mol} \mathrm{l}^{-1}$ hydrochloric acid, although in these conditions only some part of iron in the samples is extracted (Table 1). In order to verify the above observations, the extraction of water solution of ferritin was conducted (in the conditions identical to the described above) (Fig. 4). The iron speciation during the extraction in room temperature was confirmed, as well as its disturbance when the samples were heated. In these conditions, the partial release of iron probably occurs.

\section{Proposed Methodology for the Speciation Analysis of Food} Samples

Based on the studies presented above, the methodology of determination of iron forms in food samples may be
Fig. 4 Presence of ionic Fe and Fe complexed in ferritine water solution and after the extraction procedure $(0.1,0.5,1.0,2.0 \mathrm{M}$ hydrochloric acid concentration $\mathrm{mol}^{-1}$ )

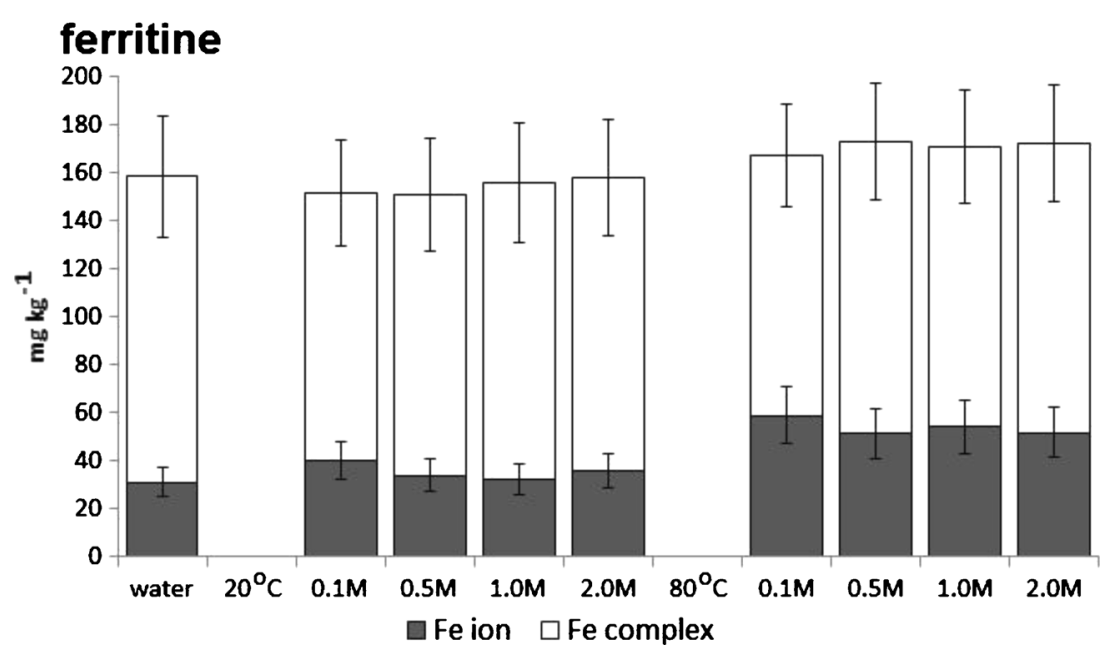


developed. Samples should be dried at $50{ }^{\circ} \mathrm{C}$, ground to grain diameter $<0.1 \mathrm{~mm}$ and sieved. Then, $2.0 \mathrm{~g}$ of a sample should be extracted with $20.0 \mathrm{ml} 2.0 \mathrm{~mol} \mathrm{l}^{-1}$ hydrochloric acid, simultaneously at room temperature (approx. $25^{\circ} \mathrm{C}$ ) for $60 \mathrm{~min}$ under cover and at $80{ }^{\circ} \mathrm{C}$ for $60 \mathrm{~min}$ under reflux condenser. After being filtered through a medium-size qualitative filter (rinsed with $200 \mathrm{ml}$ distilled water) and filled up to $20.0 \mathrm{ml}$, solutions are obtained, which (after being dissolved ten times directly before the analysis) are subjected to analysis. The determinations include the content of ionic iron in $\mathrm{Fe}(\mathrm{II})$ and $\mathrm{Fe}(\mathrm{III})$ forms, the total iron content and, based on the total iron content and ionic iron content - the content of iron in organic and inorganic complexes, including ferritin (Fig. 1).

The comparison of the percentage content of iron form in a sample subjected to extraction in room temperature and a sample extracted at $80{ }^{\circ} \mathrm{C}$ allows for the assessment to what extent the latter method contributed to the disturbance of iron speciation in a sample (Table 1). Moreover, assuming the percentage participation of iron forms in a sample extracted in room temperature as one representative for iron speciation in samples, the correction of the iron content for extraction at $80^{\circ} \mathrm{C}$ is possible. This may be done as a simple re-calculation of the percentage iron form content (obtained during the analysis of a solution from the first extraction) for the total

Table 2 The results of correction of iron forms concentration in samples extracted by $2 \mathrm{~mol}^{-1}$ hydrochloric acid (w) based on the results obtained for extraction by $2 \mathrm{~mol}^{-1}$ hydrochloric acid in ambient temperature (a) and $80^{\circ} \mathrm{C}$

\begin{tabular}{|c|c|c|c|c|c|c|c|c|}
\hline \multirow{2}{*}{$\begin{array}{l}\text { Sample } \\
\text { description }\end{array}$} & \multicolumn{4}{|c|}{ Before correction } & \multicolumn{4}{|c|}{ After correction } \\
\hline & $\begin{array}{l}\mathrm{Fe}(\mathrm{II}) \\
\left(\mathrm{mg} \mathrm{kg}^{-1}\right)\end{array}$ & $\begin{array}{l}\text { Fe complex } \\
\left(\mathrm{mg} \mathrm{kg}^{-1}\right)\end{array}$ & $\begin{array}{l}\mathrm{Fe}(\mathrm{II}) \\
(\%)\end{array}$ & $\begin{array}{l}\text { Fe compl } \\
(\%)\end{array}$ & $\begin{array}{l}\mathrm{Fe}(\mathrm{II}) \\
\left(\mathrm{mg} \mathrm{kg}^{-1}\right)\end{array}$ & $\begin{array}{l}\text { Fe complex } \\
\left(\mathrm{mg} \mathrm{kg}^{-1}\right)\end{array}$ & $\begin{array}{l}\mathrm{Fe}(\mathrm{II}) \\
(\%)\end{array}$ & $\begin{array}{l}\text { Fe compl } \\
(\%)\end{array}$ \\
\hline $3 \mathrm{a} 2.0$ & 41 & 54 & 43.4 & 56.6 & & & & \\
\hline $3 \mathrm{w} 2.0$ & 89 & 25 & 77.9 & 22.1 & 49 & 65 & 43.4 & 56.6 \\
\hline $4 \mathrm{a} 2.0$ & 5.9 & 2.7 & 68.6 & 31.4 & & & & \\
\hline $4 \mathrm{w} 2.0$ & 31 & 3.2 & 90.6 & 9.4 & 23 & 11 & 68.6 & 31.4 \\
\hline $5 \mathrm{a} 2.0$ & 70 & 73 & 49.0 & 51.0 & & & & \\
\hline $5 w 2.0$ & 234 & 31 & 88.3 & 11.7 & 130 & 135 & 49.0 & 51.0 \\
\hline $6 \mathrm{a} 2.0$ & 31 & 66 & 32.2 & 67.8 & & & & \\
\hline $6 \mathrm{w} 2.0$ & 115 & 13 & 89.8 & 10.2 & 41 & 87 & 32.2 & 67.8 \\
\hline $7 \mathrm{a} 2.0$ & 9.1 & 20 & 31.8 & 68.2 & & & & \\
\hline $7 \mathrm{w} 2.0$ & 32 & 25 & 55.9 & 44.1 & 18 & 39 & 31.8 & 68.2 \\
\hline $8 \mathrm{a} 2.0$ & 5.7 & 10 & 37.3 & 62.7 & & & & \\
\hline $8 \mathrm{w} 2.0$ & 18 & 8 & 69.1 & 30.9 & 10 & 17 & 37.3 & 62.7 \\
\hline $10 \mathrm{a} 2.0$ & 16 & 20 & 45.0 & 55.0 & & & & \\
\hline $10 \mathrm{w} 2.0$ & 36 & 15 & 70.2 & 29.8 & 23 & 28 & 45.0 & 55.0 \\
\hline $11 \mathrm{a} 2.0$ & 1.1 & 11 & 9.1 & 90.9 & & & & \\
\hline $11 \mathrm{w} 2.0$ & 7.9 & 8.9 & 47.0 & 53.0 & 1.5 & 15 & 9.1 & 90.9 \\
\hline $12 \mathrm{a} 2.0$ & 8.7 & 8.6 & 50.4 & 49.6 & & & & \\
\hline $12 \mathrm{w} 2.0$ & 5.5 & 8.7 & 38.7 & 61.3 & 7.2 & 7.0 & 50.4 & 49.6 \\
\hline $13 \mathrm{a} 2.0$ & 0 & 63 & 0.0 & 100.0 & & & & \\
\hline $13 \mathrm{w} 2.0$ & 49 & 101 & 32.9 & 67.1 & 0.0 & 150 & 0.0 & 100.0 \\
\hline $17 \mathrm{a} 2.0$ & 22 & 36 & 37.9 & 62.1 & & & & \\
\hline $17 \mathrm{w} 2.0$ & 61 & 17 & 77.9 & 22.1 & 29 & 48 & 37.9 & 62.1 \\
\hline $19 \mathrm{a} 2.0$ & 44 & 72 & 37.8 & 62.2 & & & & \\
\hline $19 \mathrm{w} 2.0$ & 71 & 64 & 52.3 & 47.7 & 51 & 84 & 37.8 & 62.2 \\
\hline $20 \mathrm{a} 2.0$ & 30 & 80 & 27.6 & 72.4 & & & & \\
\hline $20 \mathrm{w} 2.0$ & 67 & 73 & 48.1 & 51.9 & 39 & 101 & 27.6 & 72.4 \\
\hline $23 \mathrm{a} 2.0$ & 453 & 1,059 & 27.6 & 64.7 & & & & \\
\hline $23 \mathrm{w} 2.0$ & 1,156 & 1,324 & 43.6 & 49.9 & 734 & 1,716 & 27.6 & 64.7 \\
\hline $24 \mathrm{a} 2.0$ & 3.7 & 14 & 21.1 & 78.9 & & & & \\
\hline $24 \mathrm{w} 2.0$ & 16 & 6.9 & 70.4 & 29.6 & 4.9 & 18 & 21.1 & 78.9 \\
\hline
\end{tabular}


iron content obtained in the solution analysis during the second extraction (Table 2). This allows for the determination of not only the iron content, but also its speciation in the studied samples. The developed methodology allows for a simple and available laboratory analysis of iron speciation in food samples.

\section{Results of Iron Forms Determination in Food Samples}

Due to the slight assimilation of the Fe(III) form, its presence in foodstuffs is very undesirable (Goto et al. 1999). Only in one of the analyzed foodstuffs was the presence of Fe(III) form found. On the other hand, the average content of the $\mathrm{Fe}$ (II) form was about $38 \pm 14 \%$ of the total Fe content, and it never exceeded $70 \%$ of the total Fe content for any of the analyzed samples. It means that in most of studied samples the overwhelming form was complexed iron (including ferritin), which is assimilate best. The complexed iron constitutes the average $68 \pm 14 \%$ of total iron content. This indicates that iron-fortified food is very useful in diet supplementation in cases of iron deficiency (Goto et al. 1999; Lucca et al. 2001).

\section{Conclusion}

A simple and available determination of content of iron forms in food samples was presented in this paper. The single analytical procedure combines well-known and widely used methods of determination of particular iron forms (Fe(II), $\mathrm{Fe}(\mathrm{III}))$ and the total iron content. The methodology of iron extraction has been developed, as well as a method of elaborating results in order to obtain information on the content (high recovery criterion) and iron speciation (percentage participation of determined forms of this element). The determination methodology for the content of iron forms in food products is simple, especially in comparison with other procedures of iron determination (Signo et al. 2005) and its application is possible in any laboratory without special equipment for the determination of iron content in complexes, including those with ferritin. The presented analytical procedure is a new approach in food analysis, which allows for an easy and quick assessment of bioactive food properties.

Acknowledgements The research was conducted and partly funded within the POIG 01.01.02 -00-061/09 project "New bioactive food with designed functional properties", carried out by the Poznan University of Life Sciences.

Conflict of Interest Przemyslaw Niedzielski declares that he has no conflict of interest. Magdalena Zielinska-Dawidziak declares that she has no conflict of interest. Lidia Kozak declares that she has no conflict of interest. Pawel Kowalewski declares that he has no conflict of interest. Barbara Szlachetka declares that she has no conflict of interest. Sylwia Zalicka declares that she has no conflict of interest. Weronika Wachowiak declares that she has no conflict of interest. This article does not contain any studies with human or animal subjects.

Open Access This article is distributed under the terms of the Creative Commons Attribution License which permits any use, distribution, and reproduction in any medium, provided the original author(s) and the source are credited.

\section{References}

Andrews NC, Schmidt PJ (2007) Iron homeostasis. Annu Rev Physiol 69:69-85

Feres MA, Reis BF (2005) A downsized flow set up based on multicommutation for the sequential photometric determination of iron(II)/iron(III) and nitrite/nitrate in surface water. Talanta 68:422428

Filik H, Giray D (2012) Cloud point extraction for speciation of iron in beer samples by spectrophotometry. Food Chem 130: 209-213

Galhardo CX, Masini JC (2001) Sequential injection analysis as a tool for in situ monitoring of $\mathrm{Fe}(\mathrm{II}), \mathrm{Fe}(\mathrm{III}), \mathrm{NO}^{3-}$ and $\mathrm{NO}^{2-}$ in natural and waste waters. Anal Chim Acta 438:39-48

Goto F, Yoshihara T, Shigemoto N, Toki S (1999) Iron fortification of rice seed by the soybean ferritin gene. Nat Biotechnol 17:282-286

Harvey AE, Smart JA, Amis ES (1955) Simultaneous spectrophotometric determination of iron (II) and total iron with 1,10-phenanthroline. Anal Chem 27:26-29

Hoppler M, Schönbächler A, Meile L, Hurrell RF, Walczyk T (2008) Ferritin-iron is released during boiling and in vitro gastric digestion. J Nutr 138:878-884

Hosseinimehr SJ, Bagheri G, Gholipoor M, Mokarami H (2001) Comparative spectrophotometric and atomic absorption determination of iron content in wheat flour. J Biol Sci 7:451-453

Kalgaonkar S, Lönnerdal B (2009) Receptor-mediated uptake of ferritinbound iron by human intestinal Caco-2 cells. J Nutr Biochem 20: 304-311

Kochana J, Parczewski A (1997) New method of simultaneous determination of $\mathrm{Fe}$ (II) and $\mathrm{Fe}$ (III) by two-component photometric titration. Chem Anal (Warsaw) 42:411-416

Kozak L, Niedzielski P, Wachowiak W (2013) The tandem analytical method of flow injection diode array spectrophotometry and flame atomic absorption spectrometry (FI DAD(Vis)-FAAS) in iron speciation studies using 1,10-phenanthroline complexes. Microchem J 110:54-60

Liu X, Theil EC (2005) Ferritins: dynamic management of biological iron and oxygen chemistry. Acc Chem Res 38:167-175

Lönnerdal B (2003) Genetically modified plants for improved trace element nutrition. J Nutr 133:1490-1493

Lozano-Camargo ML, Rojas-Hernandez A, Gomez-Hernandez M, Pacheco-Hernandez ML, Galicia L, Ramirez-Silva MT (2007) UV-visible spectroscopic and electrochemical study of the complex formation between $\mathrm{Fe}(\mathrm{II})$ and 5-amino-1,10phenantroline (5-Aphen) in aqueous solution. Talanta 72 : $1458-1468$

Lucca P, Hurrell R, Potrykus I (2001) Genetic engineering approaches to improve the bioavailability and the level of iron in rice rains. Theor Appl Genet 102:392-397

McKie AT, Barrow D, Latunde-Dada GO, Rolfs A, Sager G, Mudaly E, Mudaly M, Richardson C, Barlow D, Bomford A, Peters TJ, Raja KB, Shirali S, Hediger MA, Farzaneh F, Simpson RJ (2001) An iron regulated ferric reductase associated with the absorption of dietary iron. Science 291:1755-1799 
Schönfeldt HC, Hall NG (2011) Determining iron bio-availability with a constant heme iron value H.C. J Food Compos Anal 24:738-740

Signo P, Barassi A, Novario R, Melzi d'Eril GV (2005) Preliminary evaluation of the performance of a new, highly sensitive commercial immunoassay for serum ferritin determination. Clin Chem Lab Med 43:883-885

Tarafder PK, Thakur R (2005) Surfactant-mediated extraction of iron and its spectrophotometric determination in rocks, minerals, soils, stream sediments and water samples. Microchem J 80: $39-43$

Theil EC, Chen H, Miranda C, Janser H, Elsenhans B, Núñez MT, Pizarro F, Schümann K (2012) Absorption of iron from ferritin is independent of heme iron and ferrous salts in women and rat intestinal segments. J Nutr 142:478-483

Whitehead D, Malik SA (1975) Determination of ferrous and total iron in silicate rocks by automated colorimetry. Anal Chem $47: 554-556$ 